\title{
Transitory disturbances in growing lactating rabbits after transient doe-litter separation
}

\author{
Pilar GARCÍA REBOLlAR ${ }^{\mathrm{a} *}$, Ana ESPINOSA ${ }^{\mathrm{a}}$, Pedro Luis LORENZO ${ }^{\mathrm{b}}$, \\ Rosa CARABAÑO ${ }^{a}$ \\ a Departamento de Producción Animal, Escuela Técnica Superior de Ingenieros Agrónomos, \\ Universidad Politécnica de Madrid, Spain \\ ${ }^{\text {b }}$ Departamento de Fisiología Animal, Facultad de Veterinaria, Universidad Complutense de Madrid, \\ 28040 Madrid, Spain
}

(Received 24 April 2004; accepted 28 June 2004)

\begin{abstract}
To determine the effect of a transient doe-litter separation $(48 \mathrm{~h})$ on milk production and feed intake from 1 to 21 days post-partum, a control group (C) in which litters had free access to nursing, and a biostimulated group (B) in which litters were separated from their does from $\mathrm{d} 9$ to $\mathrm{d} 11$ post-partum were used. Total milk production was higher in (C) than in (B) does $(5090 \pm 1.1 \mathrm{~g}$ vs. $4593 \pm 150 \mathrm{~g}, P<0.05)$. On days $12,13,14$ and 15 of the lactation period, milk production was 40\% $(P<0.0001), 18 \%(P<0.05), 15 \%(P<0.05)$, and 15\% $(P<0.01)$ higher in $(\mathrm{C})$ than in $(\mathrm{B})$, respectively. No significant differences were observed in feed intake during the period studied (7961 $\pm 352 \mathrm{~g}$ in (C) does, and $7834 \pm 329 \mathrm{~g}$ in (B) does). After fasting, 11-day-old kits showed lower gut weight, body weight, empty stomach relative weight (RW), stomach content RW and small intestine RW $(P<0.05)$, but the differences disappeared at 21 days of age. A reduction in villous height $(P<0.065)$ was observed in separated kits at 11 days old compared to 9- and 11-day-old control kits $(579.0 \pm 28.4$ vs. $664.64 \pm 27.6$, and $724.33 \pm 24.1 \mu \mathrm{m}$, respectively), but no differences were observed at either 16 or 21 days of age. Specific jejunal lactase activity increased significantly in 11-day-old separated kits $(P<0.05)$. A significant increase in sucrase activity at 21 days in both groups $(P<0.05)$ was detected. In conclusion, a fasting period of $48 \mathrm{~h}$ at 9 days of age does not compromise the subsequent development of certain digestive parameters of young rabbits.
\end{abstract}

doe-litter separation / enzyme activities / milk production / villi height

\section{INTRODUCTION}

In rabbit does, pregnancy and lactation occur concurrently because they can be mated shortly after parturition and throughout lactation. Normally, rabbit does are mated 10-11 days post-partum, but reduction in fertility and sexual receptivity rates observed during this lactation period appear to be influenced by hormonal antagonisms between blood prolactin (PRL) and gonadotrophin concentrations [1-4]. Several studies on the stimulation of ovarian activity have demonstrated the influence of the separation of does from their litters for short time periods prior to artificial insemination [5].

The absence of a suckling period results in milk accumulation in the mammary alveoli that could impair gland activity, as well as kit growth and welfare. Problems induced

* Corresponding author: prebollar@pan.etsia.upm.es 
in young animals by transient weaning are caused by changes in intestinal structure and specific loss of digestive enzymes rather than by any gross change in absorptive function $[6,7]$. After weaning, the pigs showed a reduction in intestinal villous height (villous atrophy) and an increase in crypt depth (crypt hyperplasia) [6]. Likewise, in early weaned rabbits (25 days old), a similar observation was made [8], generally associated to reductions in the specific activity of brushborder enzymes, such as lactase and sucrose.

This study was aimed at characterising the impact of a 48-h fasting interval on the histological structure and jejunal enzyme activity of 9-, 11-, 16- and 21-day-old rabbits, and the effect of this absence of suckling on milk production and feed intake of does.

\section{MATERIALS AND METHODS}

\subsection{Trial 1: effect of biostimulation on milk production and feed intake of does}

All the experiments were carried out with Californian $\times$ New Zealand White crossbreed rabbits of the Animal Production Department. Does and pups had free access to a commercial diet (Lab Rabbit Chow, Purina, Torrejón de Ardoz, Madrid; 15.5\% crude protein, $2.9 \%$ fat y $13.5 \%$ crude fiber) and tap water. The does were housed in individual metal cages $(500 \times 700 \times 300 \mathrm{~mm})$. A cycle of $16 \mathrm{~h}$ of light and $8 \mathrm{~h}$ of darkness was used throughout the experiment.

Sixteen multiparous, lactating does between 3 and 6 kindlings with more than 7 pups/kindling were randomly allocated to one of the two groups: a control group and a biostimulated group (eight per group). After kindling, the nest boxes were closed. Suckling was controlled from parturition day to the 21 st day of lactation, opening the nest box at 9:00 a.m. and closing it after nursing. Milk production was estimated daily from weight loss in the does after suckling, from parturition to day 21 of the lactating period. Both groups of does were reared in the same way until day 9. After that, the separated groups were not allowed to suckle until day 11 . The does were weighed weekly, and feed intake was determined at that time.

\subsection{Trial 2: effect of biostimulation on certain digestive, morphological and physiological parameters of young rabbits}

The study of digestive, enzymatic and histological parameters was conducted in kits from 48 multiparous does, with 3 to 5 kindlings and more than 7 kits each. Ninety-six does were separated from their litters from days 9 to 11 of lactating period, and seventytwo were considered as the control group. The litters nursed before the nest box was closed at 9:00 a.m. in both groups of animals.

All animals (two per doe or litter) were slaughtered by cervical dislocation. Fortyeight kits belonging to the control group (twelve animals per day), were slaughtered after $2 \mathrm{~h}$ of suckling on days 9,11, 16 and 21 post-partum. In the biostimulated group, twelve kits were slaughtered after a 48-h fast (day 11 post-partum) and twenty-four kits (twelve per day) on days 16 and 21 of age.

All kits were weighed before slaughter. Just after slaughter, the gastrointestinal tract was removed and weighed, as well as the full and empty stomach, small and large intestines. Two samples were taken from the middle part of the jejunum. One was stored at $-20{ }^{\circ} \mathrm{C}$ for further analyses of disaccharidase activities and another one to study intestinal morphology. Jejunal samples were rinsed with $0.4 \mathrm{M} \mathrm{KCl}$ to remove intestinal contents and placed in a 10\%-buffered neutral formaldehyde solution ( $\mathrm{pH} 7.2$ to 7.4). All samples were gradually dehydrated with increasing concentrations of ethyl alcohol (50 to $100 \%$ ). These dehydrated specimens were first embedded in paraffin, prepared by sectioning at $6 \mu \mathrm{m}$, and stained with hematoxylin and eosin. The sections were analysed under a light microscope (Olympus 
BX40, Olympus Optical Co. [Europe] GMBH, 20097, Hamburg, Germany), to determine their morphometric index by computerassisted image analysis (The Image J v 1.26. Wayne Rasband, National Institutes of Health, Bethesda, MD 20892, USA).

The intestinal histology study was conducted according to Hampson [9]. Villi height (from the top of the villi to the villi crypt junction) at three cross sections was determined. Only vertically-oriented villi were selected for measurements, and the mean value from 30 villi was used as the average value for further analyses.

To determine disaccharidase activity, the samples were thawed and placed into vials containing distilled water to make a $1 / 20$ (wt.vol ${ }^{\mathrm{a}}$ ) mucosal homogenate following homogenisation for $30 \mathrm{~s}$ in a polytron (Model RE 16, Janke \& Kunkel, IKA-Labortechnik). The homogenates were kept in vials at $-20{ }^{\circ} \mathrm{C}$ for further analyses of lactase (EC 3.2.1.23) and sucrase (EC 3.2.1.48) activity by using lactose and sucrose as substrates, respectively. Glucose released at $37{ }^{\circ} \mathrm{C}$ for 30 min was measured by the glucose oxidase-peroxidase method [10].

Aliquots of homogenates of the jejunum were taken for determination of protein concentration using a commercial kit (SIGMA Procedure No. P-5656) based on the Lowry method, modified by Peterson [11].

Rabbits were handled according to the guidelines on experimentation animal care published in the Spanish Royal Decree 223/ 88 [12].

\subsection{Statistical analysis}

All analyses were conducted using the Statistical Analysis System Software for Windows, release 8.2 [13]. The lactation trial was analysed as a randomised complete design with treatment (separated does or not) as the main source of variation. The interactions between treatment and day of lactation were studied using a repeated measures analysis. The homogeneity of variances of different segments of the gastrointestinal tract and individual body weight was checked by a t-test procedure. Since the relative full stomach weight and individual body weight variances were not homogeneous, logarithmic conversion of individual body weights and root square conversion of relative full stomach weights were carried out to stabilise the variances. All digestive parameters were expressed as a percentage of body weight.

\section{RESULTS}

\subsection{Trial 1: milk production of does and feed intake}

The results of daily milk production estimated from weight loss in does during suckling - , and feed intake are shown in Figure 1. Total milk production (during the examined $21 \mathrm{~d}$ lactation period) was $11 \%$ higher in control does than in the biostimulated group $(5090 \pm 161 \mathrm{~g}$ vs. $4593 \pm 150 \mathrm{~g}$; $P=0.044$ ). Milk production between days 1 and 9 of the lactating period increased similarly in both groups. Between days 9 and 11 , milk production of the control does increased by $6.8 \%$, whereas biostimulated does increased by $10.5 \%$, but no significant differences were observed. However, during the four days following the absence of suckling (days 12, 13, 14 and 15 of the lactating period), milk production of biostimulated does decreased $40 \%, 18 \%, 15 \%$ and $15 \%$, respectively $(P=0.0001, P=0.041$, $P=0.038$ and $P=0.013$ ). No differences between day 16 and the end of controlled lactation (day 21) were observed in the daily milk production between groups.

No significant differences were observed in the total feed intake (during the examined $21 \mathrm{~d}$ period) between control and biostimulated does (7961 $\pm 352 \mathrm{~g}$ in control group and $7834 \pm 329 \mathrm{~g}$ in the biostimulated group). The average daily feed intake was $376 \pm$ $16 \mathrm{~g} \cdot \mathrm{d}^{-1}$. When comparing the feed intake of control and biostimulated does every day, on the day before separation (day 9) we 


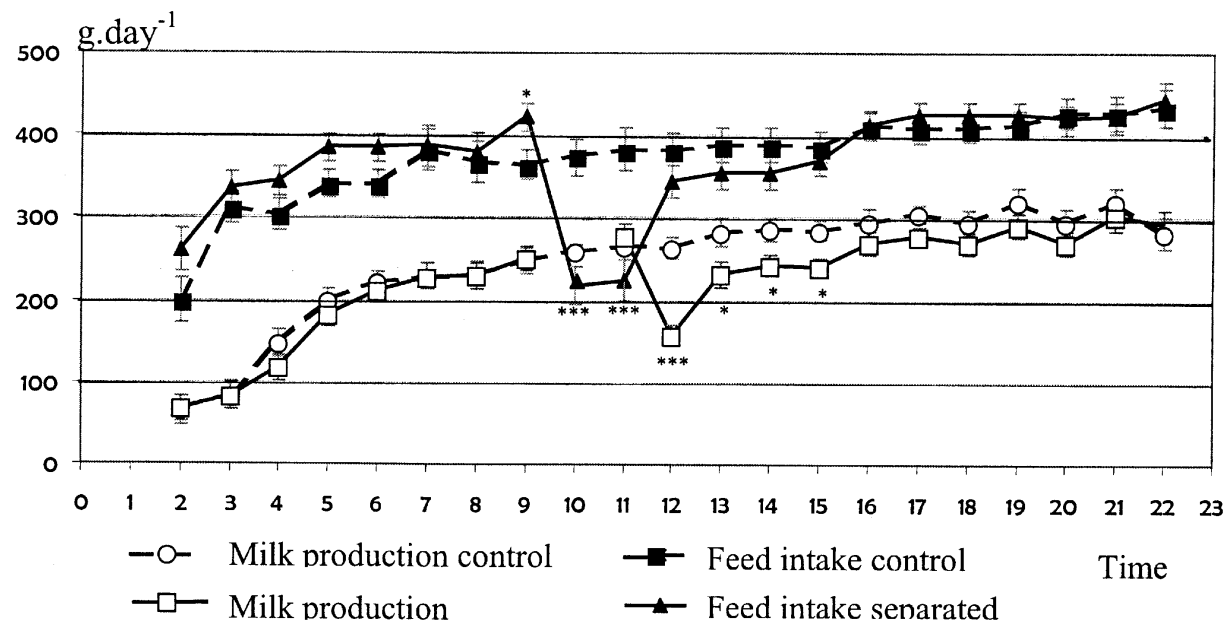

Figure 1. Milk production and feed intake of multiparous does having more than 7 kits and submitted or not to 48 -h of separation on day 9 of the lactating period. $* P<0.05$. *** $P<0.001$.

observed a significant increase $(P=0.03)$ of $13.9 \%$ in biostimulated does, while on days 10 and 11 intake decreased by $41.8 \%$ and $42.2 \%$, respectively $(P=0.0003$ and $P=$ 0.0008). After that, feed intake was similar in both groups.

\subsection{Trial 2: effect of biostimulation on certain digestive, morphological and physiological parameters of young rabbits}

The effect of fasting and the progress observed with age in body weight, relative body weight of the gastrointestinal tract, full and empty stomach, stomach content, small and large intestine of 9-, 11-, 16-, and 21-day-old rabbits are shown in Table I.

All young rabbits separated from their mothers survived. The body weight of 9day-old rabbits two hours after suckling was $163.7 \pm 8.3 \mathrm{~g}$, but after a 48 -h fast, their body weight decreased significantly $(P<0.05)$ compared to the controls. This difference disappeared at 16 days of age $(286.9 \pm 13.9 \mathrm{~g}$ vs. $264.4 \pm 11.8 \mathrm{~g}$ for control and separated group, respectively).
A 48-hour fast led to a decrease $(P<0.05)$ in relative gastrointestinal tract weight, relative full stomach weight and stomach content in 11-day-old kits by $62 \%, 76 \%$ and $87 \%$, compared to control rabbits, respectively. These differences remained at 16 days of age, but the degree of decrease was smaller $13 \%, 19 \%$ and $23 \%$, respectively $(P<0.05)$. At 21 days of age, the differences between control and fasted animals disappeared. No differences were detected in relative empty stomach weight.

Relative small intestine weight was $12 \%$ $(P<0.05)$ lower in $48 \mathrm{~h}$ fasted than in control young rabbits. The differences disappeared at 16 days of age. The treatment did not significantly affect the progress in relative large intestine weight. Relative large intestine weight was affected by age. Conversely, average increases $(P<0.05)$ were observed from 11 to $16 \mathrm{~d}$, as well as from 16 to $21 \mathrm{~d}$ (39\% and $51 \%$, respectively).

The effect of treatment on the morphology of the jejunal mucose is shown in Table I. In control rabbits, villous height tended to increase from days 9 to 16 , but then it 
Table I. Effect of age and doe-litter separation on BW (body weight) and gastrointestinal tract, full stomach, empty stomach, stomach content, small intestine and large intestine relative to body weight, and villi height of young lactating rabbits.

\begin{tabular}{|c|c|c|c|c|c|c|c|c|c|}
\hline \multirow{2}{*}{ Age (days) } & \multicolumn{4}{|c|}{ Control } & \multicolumn{5}{|c|}{ Separated } \\
\hline & 9 & 11 & 16 & 21 & 11 & 16 & 21 & $P^{1}$ & $\mathrm{SEM}^{2}$ \\
\hline BW (g) & $163.75 \mathrm{e}$ & $200.67 d$ & $286.91 b c$ & $375.25 \mathrm{a}$ & $137.25 \mathrm{e}$ & $264.42 \mathrm{c}$ & $315.42 \mathrm{a}$ & 0.0001 & 26.6 \\
\hline Gut tract (\%BW) & $17.8 \mathrm{a}$ & $18.6 \mathrm{a}$ & $19.2 \mathrm{a}$ & $18.6 \mathrm{a}$ & $7.12 b$ & $16.7 \mathrm{c}$ & $18.6 \mathrm{a}$ & 0.0001 & 0.26 \\
\hline Full stomach (\%BW) & $13.7 \mathrm{a}$ & $13.6 \mathrm{a}$ & $13.3 \mathrm{a}$ & $11.4 \mathrm{~b}$ & $3.27 \mathrm{c}$ & $10.7 \mathrm{~b}$ & $11.5 \mathrm{~b}$ & 0.0001 & 0.25 \\
\hline Empty stomach (\%BW) & 1.72 & 1.64 & 1.64 & 1.65 & 1.75 & 1.64 & 1.55 & 0.2034 & 0.03 \\
\hline Stomach content $(\% \mathrm{BW})$ & $12.0 \mathrm{a}$ & $12.0 \mathrm{a}$ & $11.7 \mathrm{a}$ & $9.78 b$ & $1.51 \mathrm{c}$ & $9.02 b$ & $9.94 b$ & 0.0001 & 0.24 \\
\hline Small intestine (\%BW) & $2.97 \mathrm{c}$ & $2.73 \mathrm{c}$ & $3.20 \mathrm{~b}$ & $3.46 \mathrm{a}$ & $2.41 \mathrm{~d}$ & $3.17 \mathrm{~b}$ & $3.67 \mathrm{a}$ & 0.0157 & 0.05 \\
\hline Large intestine (\%BW) & $1.15 \mathrm{c}$ & $1.37 \mathrm{c}$ & $1.97 \mathrm{~b}$ & $3.07 \mathrm{a}$ & $1.46 \mathrm{c}$ & $1.92 b$ & $2.81 \mathrm{a}$ & 0.0001 & 0.03 \\
\hline Villi height $(\mu \mathrm{m})$ & 664. 63ab & $724.33 a$ & $756.17 \mathrm{a}$ & $638.33 b$ & $579.0 \mathrm{~b}$ & 689.0ab & $628.1 \mathrm{~b}$ & 0.0393 & 25.2 \\
\hline
\end{tabular}

${ }^{1}$ Signification level. Significant differences are indicated with different letters.

${ }^{2}$ Standard error of the mean.

decreased by $16 \%$ at $21 \mathrm{~d}(P<0.01)$. At $11 \mathrm{~d}$ of age, the villous height of separated animals decreased by $20 \%$ compared to that of control rabbits of the same age $(579 \pm 28.4$ vs. $724,33 \pm 22.5 ; P<0.0003)$. No differences were observed in villous height between control and fasted young rabbits of the same age, neither on 16 or 21 days.

An increase $(P<0.05)$ in lactase activity of 23 and $30 \%$ from 9 to 11 days of age both in control and separated young rabbits was observed (Fig. 2). At 16 and 21 days of age, lactase activity was 31 and $20 \%(P<0.05)$ higher in fasted than in control young rabbits.

Sucrose activity is shown in Figure 3. Treatment did not affect sucrose activity, and no interaction was observed between the main effects (age and doe separation). No activity was detected at the age of 9 and 11 days. Sucrose activity increased from 16 to $21 \mathrm{~d}$ of age $(P<0.0001)$.

A significant increase in the protein content of intestinal mucose was observed in 11-day-old control young rabbits compared to 9- and 21-day-old ones (Fig. 4). In fasted animals, the protein content decreased by $17 \%(P<0.05)$ from 9 to $11 \mathrm{~d}$ of age. This difference between control and separated animals was not significant at 16 and 21 days of age.

\section{DISCUSION}

\subsection{Trial 1: milk production and feed intake of does}

Feed intake during the controlled lactating period $(21 \mathrm{~d})$ corresponded to those observed in the literature [14], both in control and separated groups. Lower daily intake in does not allowed to nurse their young on days 10 and 11 could be related to lactation suppression on day 10. Later stages of milk accumulation could determine a feeling of pain or discomfort, thus decreasing feed intake. Cows submitted to once-daily milking, for example, can utilise cisternal storage, but left to a free choice with robotic milking prefer to be milked and fed concentrates four and six times per day [15]. 


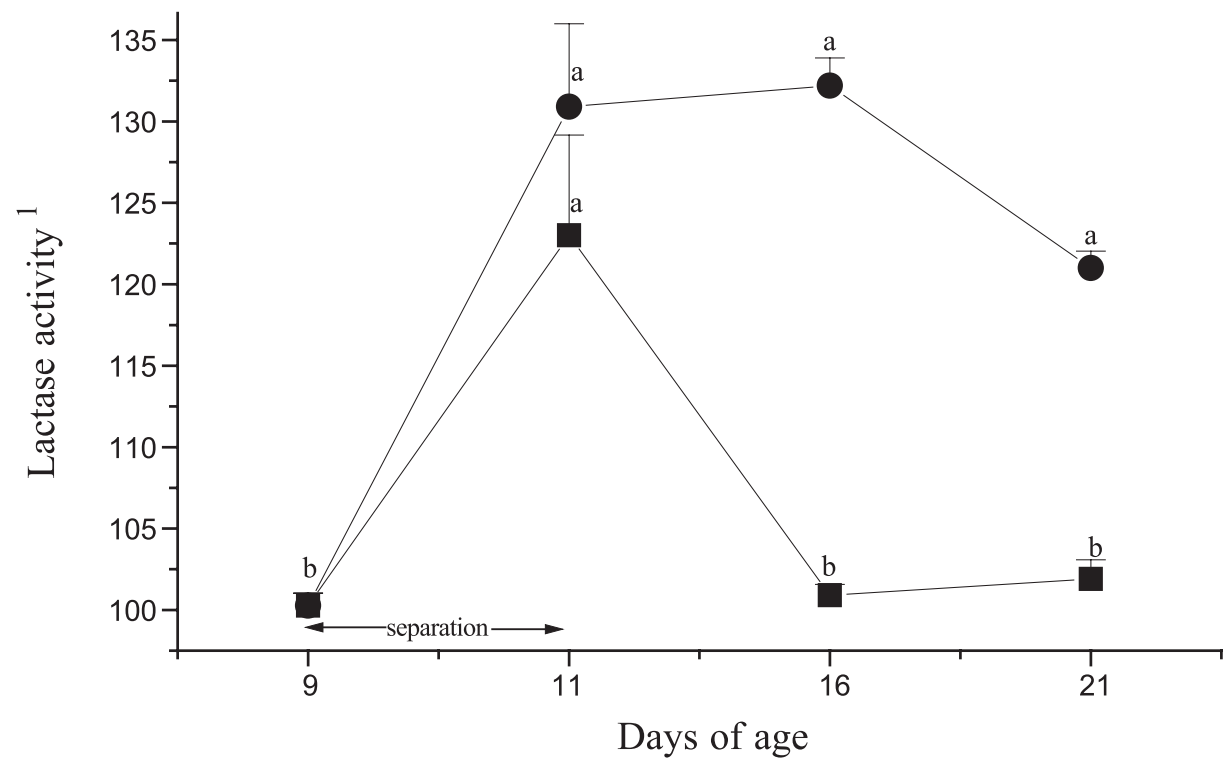

Figure 2. Jejunal lactase activity in separated (•) and control (ם) young rabbits. Arrows indicate doe-separation interval. Each point represents the mean \pm SEM of 12 samples. Means with different letters show significant differences $(P<0.032) .{ }^{1}$ Activity unit: $\mu$ mol glucose released at $37^{\circ} \mathrm{C}$ for $30 \mathrm{~min}$.

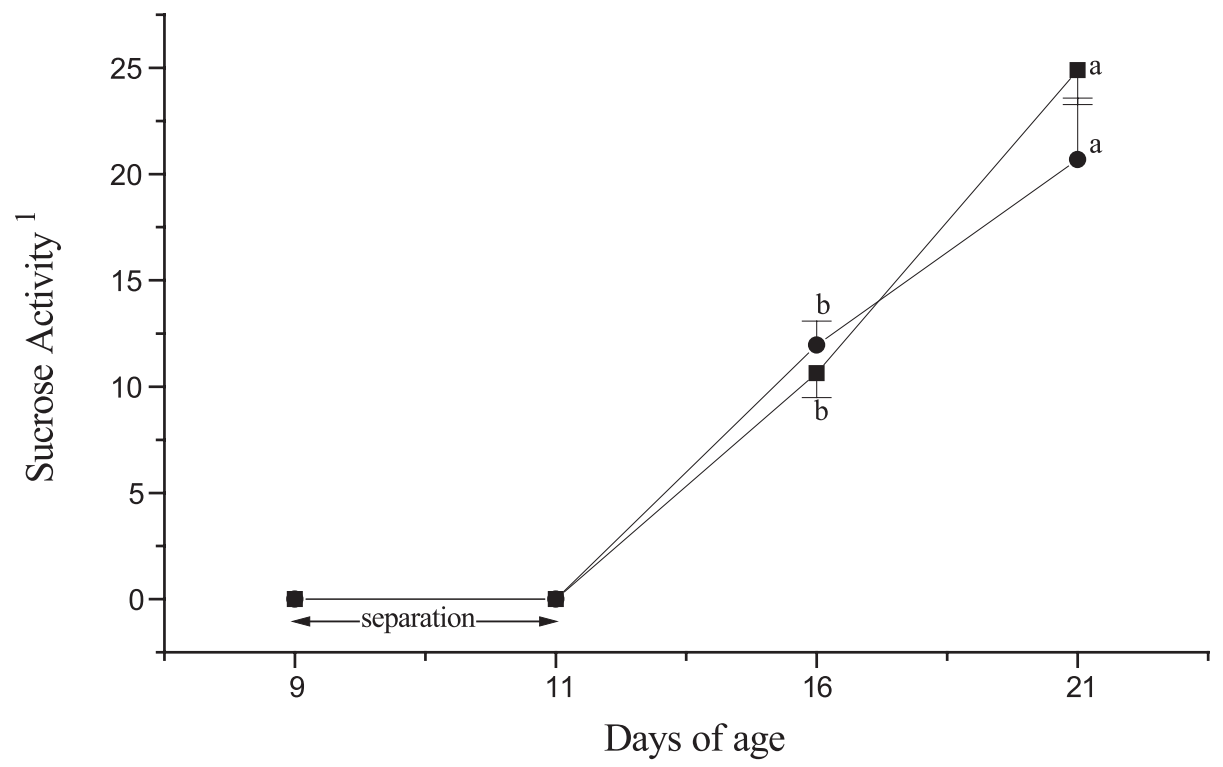

Figure 3. Jejunal sucrose activity in separated $(\bullet)$ and control $(\boldsymbol{\square})$ young rabbits. Arrows indicate doe-separation interval. Each point represents the mean \pm SEM of 12 samples. Means with different letters show significant differences $(P<0.0001) .{ }^{1}$ Activity unit: $\mu \mathrm{mol}$ glucose released at $37{ }^{\circ} \mathrm{C}$ for $30 \mathrm{~min}$. 


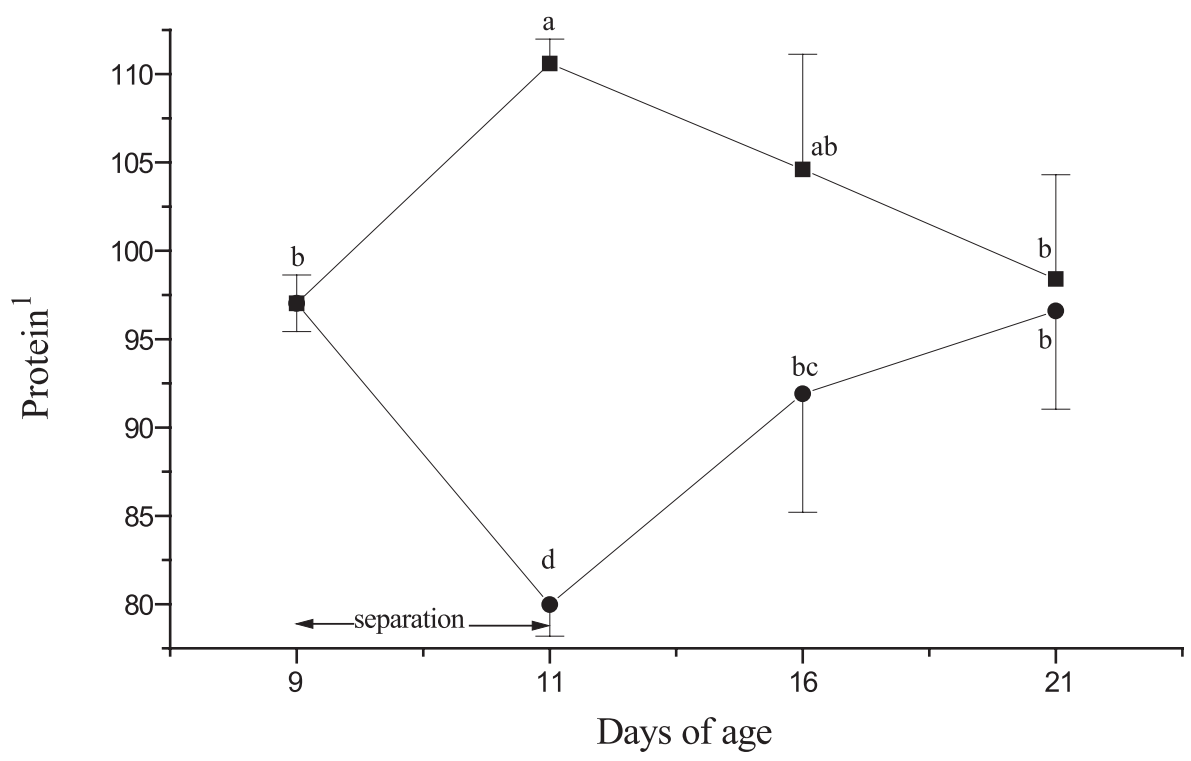

Figure 4. Soluble protein content of jejunal mucose in separated (•) and control (ם) young rabbits. Arrows indicate the doe-separation interval. Each point represents the mean \pm SEM of 12 samples. Means with different letters show significant differences $P<0.008) .{ }^{1} \mu \mathrm{g}$ protein $\cdot \mathrm{mg}^{-1} \mathrm{tissue}$.

Similar milk production was observed in separated and control does on the day following the suppression of suckling. However, on the four days following the absence of suckling, milk production in the does of the experimental group lagged behind that of the does in the control group. Other authors [16] have obtained similar results and consider that when lactating rabbits do not have access to nursing during $48 \mathrm{~h}$, milk production does not exceed the volume produced during 24-48 $\mathrm{h}$ after non-restricted suckling [17]. Rabbit does can accumulate all milk produced during $24 \mathrm{~h}$ without the need to develop storage cisterns. This is because mammary alveoli of rabbits are much more elastic, so they can accumulate increasingly concentrated milk into the alveolar lumen, even for $48 \mathrm{~h}$ after the last suckling episode [17].

Intramammary pressure changes due to milk accumulation have not been reported in rabbits. However, these changes explain milk production "losses" in cattle when they are milked once a day instead of twice a day [15]. Both the lower feed intake and the full mammary gland could adversely affect milk synthesis and secretion in rabbit does. In other species (e.g. in cows), the increase of residual milk in mammary glands due to incomplete milking leads to a decreased secretory efficiency in subsequent lactations [18].

Moreover, alterations in the rhythm of milk secretion results in changes in milk composition [16], so milk secreted two days after omission of suckling is more concentrated. This is a characteristic feature in species with long suckling intervals, like rabbits [15]. The absence of suckling stimulus results in the involution and loss of milk-synthesising cells, which can be reversed if the stimulus is reapplied. In mice traits, the rate of apoptosis increases during litter removal and quickly returns to normal levels during resuckling [19]. 


\subsection{Trial 2: effect of biostimulation on certain digestive, morphological and physiological parameters of young rabbits}

It is widely accepted that mortality in the young rabbit is not affected by a short damlitter separation during lactation [20-26], because the volume of milk in their stomachs is enough to keep them alive. Newborn kits can miss a feed and survive for $48 \mathrm{~h}$, and older pups can miss two feeds, surviving $72 \mathrm{~h}$ without apparent harm [27].

However, a short fast during the lactating period caused an approximatevely $16 \%$ decrease in body weight, which could produce, at least temporally, a slower growth rate. Some studies point out that 24-48 h mother deprivation leads to decreased growth of the young, with 2 to $10 \%$ individual weight decreases at weaning [16, 23, 28-32]. Other authors [21,33] like our present results, did not evidence significant decreases of individual weaning weight, even 10 days after fasting, separated rabbits (21 days old) showed similar body weight values as free lactating rabbits. The conditions in this work were standardised, so lactating intensity did not affect the results because all litters had 7 pups and all does were multiparous with more than two kindlings.

Body weight at 9 days $(163.75 \pm 8.3 \mathrm{~g})$ was similar to that observed by other authors in animals of the same age $[4,35]$. The relative weight of the fall gastrointestinal tract was over $17 \%$ two hours after the last milk intake, in both 9- and 11-day-old control rabbits. This shows the ability of pups to drink up large amounts of milk during the once daily nursing, an amount which can reach $25 \%$ of their body weight [28]. When the access of the doe to the nest is free, the kit's stomach is continuously full of milk, which may explain the high relative body weight of this organ with respect to the rest of the digestive tract [34]. However, after 24 and $48 \mathrm{~h}$ of fasting, there are only remainders of milk and gastric secretion, so the loss of body weight in 11-day-old kits could be due to the reduction of stomach content weight. These differences in full stomach and in stomach content weight are still observed at 16 days of age between control and separated kits, but disappear at 21 days. There is a significant difference in the relative weight of the small intestine on $\mathrm{d} 11$ and this was confirmed by a decrease in the protein content of the small intestinal mucosa as well (Fig. 4). No significant differences were observed in relative small and large intestine weight between control and fasted rabbits at 16 days of age. Moreover, the progress of weight with age was similar and increased in both rabbit groups. However, we did not empty this segment, so we could not confirm if the weight increase was due to its content or the high growth rate of this gastrointestinal tract segment in rabbits of this age $[34,35]$.

In relation to the morphology of the small intestine, the intestinal mucose structure changes from the longer and finger-like villi seen in 9- and 16-day-old rabbits to wider, leaf-like or tongue-like villi in 21-day-old rabbits. This tendency to shorter structures continues with the age of the rabbits $[8,36]$, perhaps due to the fact that pups began to eat the same feed as their mothers around 18 days of life. At the beginning, pups take small quantities, which increase with both age and the reduction of milk production by does. This change in feed associated with weaning is one of the main reasons for the morphological and physiological changes of the villi [6].

In species like the pig, it has been reported that one of the most important stimulus for cell proliferation in the intestine is feed presence and, more specifically, nutrient flow through the small intestine [37]. The reduction of the villous height observed in 48-hfasted rabbits could be related to the absence of nutrients in the gut (like by weaning or other causes), since feed ingestion and its physical presence in the gastrointestinal tract per se are necessary for the development of the mucosal structure and function 
of the small intestine [6]. That metabolic situation could determine their reduced capacity to regenerate and maintain the intestinal mucose at a cellular level [27].

Suckling deprivation also affected the soluble protein content of small intestine mucose. In 11-day-old animals, the protein content was reduced $(P<0.05)$ in a fasted group with respect to a control group (110.6 \pm 0.38 vs. $79.97 \pm 0.78 \mu \mathrm{mol}$ protein $\cdot \mathrm{mg}^{-1}$ jejunum, respectively). These results could suggest a mucosal atrophy and a reduction in the digestive capacity of fasted animals. However, no differences were detected in lactase activity $(123 \pm 1.16$ vs. $130.9 \pm 1.1$ units of lactase $\cdot \mathrm{g}^{-1}$ tissue in the control and the separated group, respectively).

We were unable to detect sucrase activity in both groups at these ages. When studying the prenatal development of brush-border hydrolases of the most apical distribution in pigs, it has been observed that glucosidase activities (sucrase-isomaltase, maltaseglucoamylase) do not rise until postnatally [38]. In parallel to this, a fall in lactase-phloridzin hydrolase ( $\beta$-galactosidase) activity has been observed $[39,6]$, which may be associated with colostrum intake induced changes in the intestinal mucose ability to absorb and in the activity of the most apical distribution enzymes [40]. Colostrum ingestion is also associated with enhanced pinocytotic activity of the intestinal mucose and has been reported to either increase or decrease the specific activity of lactase (expressed per gram of protein) while consistently increasing the specific activities of enzymes such as maltase and aminopeptidases [40-42].

When rabbits are fasted, a lower lactase activity associated to a reduction in villous height due to their more apical distribution along the villi should be expected [43-45]. However, the results observed in this work show that the lactase activity increases. A different milk composition 12 hours after suckling omission with a reduction in lactose content has been observed by other authors [17], and could explain the variations in lactase activity. On the contrary, enzyme activities and other vital functions could be regulated by the maternal behaviour of the does. The availability of feed and nursing visit are a powerful chronometer in the young rabbit. The periodic nursing rhythm by night, rather than the influence of light, is the main external time source of information, because pups begin to open their eyes on days 9 or 10 . Various stimuli induced by the mother at nursing (tactile, thermal, nipple-pheromone...), might be able to trigger different, and possibly independent, cascades of neural and metabolic events, thus also acting as chronometers. Physiological changes associated with milk ingestion (humoral and metabolic factors associated with digestion) might act as chronometers and are likely to influence hypothalamic activity, providing a discrete timing signal [46]. A two-day long maternal deprivation in young rabbits influences differently neuro-endocrine responses both in the adrenal and the ovarian axes [47]. Although the diurnal pattern of young rabbit activity continues even if a nursing visit is omitted [46], a doe-litter separation could influence the pituitary pattern of secretion in 11-dayold lactating rabbits [48], probably also affecting the enzymatic activity circadian rhythm [49], even in 16 and 21-day-old rabbits.

We conclude that an important effect is observed in 11-day-old rabbits submitted to a transient separation and an interval of a 24-hour fast. However, it seems that these animals reach similar enzymatic and digestive levels as non-fasted animals when lactation is restored and they are over 21 days old.

\section{ACKNOWLEDGEMENTS}

Support by UPM (A0201), MCYT (AGL200200005 and AGL2002-00310) is gratefully acknowledged.

\section{REFERENCES}

[1] Lin KC, Okamura H, Mori Y. Inhibition of hCG-induced ovulation and steroidogenesis 
by short-term hyperprolactinemia in female rabbits. Endocrinol Jpn 1987, 34: 675-683.

[2] Ubilla E, Rebollar PG. Influence of the postpartum day on plasma estradiol-17 $\beta$ levels, sexual behaviour and conception rate in artificially inseminated lactating rabbits. Anim Reprod Sci 1995, 38: 337-344.

[3] Ubilla E, Rebollar PG, Pazo D, Esquifino A, Alvariño JMR. Pituitary and ovarian response to transient doe-litter separation in nursing rabbits. J Reprod Fertil 2000, 118: 361-366.

[4] Ubilla E, Rebollar PG, Pazo D, Esquifino A, Alvariño JMR. Effects of doe-litter separation on endocrinological and productivity variables in lactating rabbits. Livest Prod Sci 2000, 67: 67-74.

[5] Theau-Clèment $M$. Advances in biostimulation methods applied to rabbit reproduction. In: Proc 7th World Rabbit Sci, Vol A, 2000, p 61-79.

[6] Pluske JR, Hampson DJ, Williams IH. Factors influencing the structure and function of the small intestine in the weaned pig: a review. Livest Prod Sci 1997, 51: 215-236.

[7] Sangild PT, Silver M, Schmidt M, Fowden AL. The perinatal pig in pediatric gastroenterology. In: Tumbleson ME, Schnook L (Eds), Advances in Swine in Biomedical Research, Plenum Press, New York, 1996.

[8] Gutiérrez I, García P, Carabaño R, De Blas C. Effect of supplementation with animal plasma and antibiotics on jejunal morphology of earlyweaned rabbits. In: Proc 7th World Rabbit Congress, Valencia, Spain, Vol C, 2000, p 263 267.

[9] Hampson DJ. Alteration in piglet small intestinal structure at weaning. Res Vet Sci 1986, 40: 32-40.

[10] Dahlquist A. Method for assay of intestinal dissaccharidases. Anal Chem 1964, 7: 18-25.

[11] Peterson GL. A simplification of the protein assay method of Lowry et al. Which is more generally applicable. Ann Biochem 1977, 83: 346-356.

[12] Spanish Royal Decree 223/88. Sobre protección de los animales utilizados para experimentación y otros fines científicos. Boletín Oficial del Estado 1988, 67: 8509-8511.

[13] SAS. SAS ${ }^{\circledR}$ Propietary Software Release 8.2. SAS Inst Inc, Cary, NC, USA, 1999-2001.

[14] Nicodemus N. Recomendaciones sobre el nivel óptimo de inclusión de fibra: FND, fibra larga y LAD, en piensos de conejos de alta productividad, Tesis doctoral, Universidad Politécnica de Madrid, España, 2000.

[15] Davis SR, Farr VC, Stelwagen K. Regulation of yield loss and milk composition during once-daily milking: a review. Livest Prod Sci 1999, 59: 77-94.

[16] Szendrö ZS, Jovanczai ZS, Theau-Clément M, Radnai I, Biro-Nemeth E, Milisits G. The effect of doe-litter separation on production performance in rabbit does and their kits. World Rabbit Sci 1999, 7: 165-169.

[17] Calvert DT, Knight CH, Peaker M. Milk accumulation and secretion in the rabbit. Q J Exp Physiol 1985, 70: 357-363.

[18] Wilde CJ, Knight CH. Metabolic adaptations in mammary gland during the declining phase of lactation. J Dairy Sci 1989, 72: 1679-1692.

[19] Knight CH. The importance of cell division in udder development and lactation. Livest Prod Sci 2000, 66: 169-176.

[20] Alvariño JMR, Bueno A, Santiago ME, Del Arco JA. Effect of a doe-litter separation on survival and growth of young rabbits. World Rabbit Sci 1999, 7: 161-163.

[21] Boiti C, Bonanno A, Brecchia G, Alabiso M, Di Grigoli A, Zampini D. Influence d'une séparation mère-jeunes pendant $48 \mathrm{~h}$, sur la croissance des lapereaux et leur sensibilité à un stress. In: Proc. $9^{\mathrm{e}}$ Journ Rech Cunicole Fr, Paris, 2001, p 167-170.

[22] Bonanno A, Alabiso M, Di Grigoli A, Alicata ML. Effect of change of cage and/or $44 \mathrm{~h}$ mother-litter separation on productivity of non-receptive lactating rabbit does. Preliminary investigations. World Rabbit Sci 1999, 7: 107-111.

[23] Bonanno A, Alabiso M, Di Grigoli A, Alicata ML, Leto G. Effect of a 48 h delayed insemination with or without a $48 \mathrm{~h}$ doe-litter separation on performance of non-receptive does. World Rabbit Sci 1999, 7: 171-175.

[24] Bonanno A, Alabiso M, Di Grigoli A, Alicata ML, Montalbano L. Effect of a 48 h doe-litter separation on performance of free or controlled nursing rabbit does. In: Proc 7th World Rabbit Congress, Vol A, Valencia, Spain, 2000, p 97-103.

[25] Maertens L. Effect of flushing, mother litter separation and PMSG on the fertility of lactating does and the performance of their litter. World Rabbit Sci 1998, 6: 185-190. 
[26] Virag GY, Kustos K, Szabo L. Effect of a 48 hours doe-litter separation on rabbit doe's reproductive performance and offspring's growth. World Rabbit Sci 1999, 7: 155-159.

[27] Jilge B, Hudson R. Diversity and development of circadian rhythms in the European rabbit. Chronobiol Int 2001, 18: 1-26.

[28] Bonanno A, Di Grigoli A, Alabiso M, Boiti C. Parity and number of repeated doe-litter-separation treatments affect differently the reproductive performance of lactating does. World Rabbit Sci 2002, 10: 63-70.

[29] Castellini C, Canali C, Boiti C. Effect of mother-litter separation for 24 hours by closing the nestbox or change of cage, on rabbit doe reproductive performance. World Rabbit Sci 1998, 6: 191-203.

[30] Pavois V, Le Naour J, Ducep O, Perrin G, Duperray J. Une méthode naturelle pour améliorer la réceptivité et la fertilité des lapines allaitantes en insémination artificielle. In: Proc 6 Journ Rech Cunicole, France, La Rochelle, Vol II 1994, p 528-535.

[31] Theau-Clément M, Mercier P. Effect of a $24 \mathrm{~h}$ doe-litter separation on rabbit doe reproductive performance and growth of the young. World Rabbit Sci 1999, 7: 177-179.

[32] Tomás N, Perucho O, Catafau J, Aloi N, Rafel O, Ramón J, Gómez EA. Estímulo de la aceptación de la monta mediante el cierre del nidal en conejas. Efecto sobre las camadas en lactación. Boletín de cunicultura 1996, 86: 14-17.

[33] Alvariño JMR, Del Arco JA, Bueno A. Effect of mother-litter separation on reproductive performance of lactating rabbit females inseminated on day 4 or 11 post-partum. World Rabbit Sci 1998, 6: 191-194.

[34] Lebas F, Laplace J-P. Mensurations viscérales chez le lapin. Ann Zootech 1972, 21: 37-47.

[35] Yu B, Chiou PWS. The morphological changes of intestinal mucose in growing rabbits. Lab Anim 1997, 31: 254-263.

[36] Campín J, Gutiérrez I, Espinosa A, Carabaño R, Rebollar PG, De Blas JC. Efecto de la fuente de proteína sobre los parámetros digestivos, parámetros histológicos y digestibilidad ileal y fecal en gazapos destetados precozmente. In: Proc. XXVII Symposium de Cunicultura, Reus, Tarragona, Spain, 2002, p 117 127.

[37] Diamond JM, Karasov WH. Trophic control of the intestinal mucose. Nature (London) 1983, 304: 18.

[38] James PS, Smith MW, Tivey DR, Wilson TJG. Epidermal growth factor selectively increases maltase and sucrase activities in neonatal piglet intestine. J Physiol 1987, 393: 583-594.

[39] Gutiérrez I, Espinosa A, García J, Carabaño R, De Blas JC. Effects of levels of starch, fiber and lactose on digestion and growth performance of early-weaned rabbits. J Anim Sci 2002, 80: 1029-1037.

[40] Zhang H, Malo C, Buddington RK. Suckling induces rapid intestinal growth and changes in brush border digestive functions of newborn pigs. J Nutr 1997, 127: 418-426.

[41] Sangild PT, Fowden AL, Trahair JF. How does the foetal gastrointestinal tract develop in preparation for enteral nutrition after birth. Livest Prod Sci 2000, 66: 141-150.

[42] Wang T, Xu RJ. Effects of colostrum feeding on intestinal development in newborn pigs. Biol Neonate 1996, 70: 339-348.

[43] Marounek M, Vovk SJ, Skrivanová V. Distribution of activity of hydrolitic enzymes in the digestive tract of rabbits. Br J Nutr 1995, 73: 463-469.

[44] Tsuboi KK, Kwong LK, Neu J, Sunshine P. A proposed mechanism of normal intestinal lactase decline in the post-weaned mammal. Biochem Biophys Res 1981, p 645-652.

[45] Tsuboi KK, Kwong LK, D’Harlingue AE, Stevenson DK, Kerner JA Jr, Sunshine P. The nature of maturation decline of intestinal lactase activity. Biochim Biophys Acta 1985 . 840: 69-78.

[46] Allingham K, von Saldern C, Brennan PA, Distel H, Hudson R. Endogenous expression of c-Fos in hypothalamic nuclei of neonatal rabbits coincides with their circadian pattern of suckling-associated arousal. Brain Res 1998, 783: 210-218.

[47] Boiti C, Bonanno A, Brecchia G, Mazza F. Effects of neonatal deprivation on the neuroendocrine responses of rabbits. In: Boiti C, Gidenne T, Sabbioni E (Eds), COST ACTION 848 \& ECVAM. JRC Ispra: Proc of Joint Scientific Meeting WG1 and WG-4, 2002, p 19.

[48] Rebollar PG, Alvariño JMR, Jiménez V, Cano P, Chacón P, Esquifino AI. Effect of doe-litter separation on FSH and LH levels of young lactating rabbits: preliminary results. In: Boiti C, Gidenne T, Sabbioni E(Eds), COST ACTION 848 \& ECVAM. JRC Ispra: Proc of Joint Scientific Meeting WG1 and WG-4, 2002, p 20.

[49] Hörnicke H, Ruoff G, Vogt B, Clauss W, Ehrlein M-J. Phase relationship of the circadian rhythms of feed intake, caecal motility and production of soft and hard faeces in domestic rabbits. Lab Anim 1984, 18: 169-172. 